\title{
Evaluation of Surface Roughness of 316L Stainless Steel Substrate on Nanohydroxyapatite by Electrophoretic Deposition
}

\author{
Mohammed Jasim Kadhim Nawal Ezzat Abdulateef Makarim Hazim Abdulkareem* \\ Department of Production Engineering and Metallurgy, University of Technology, Baghdad-Iraq \\ *E-mail: engmak03@gmail.com \\ Received: 11-June-2017Ｒevised: 20-Aug.-2017 Accepted: 05-Nov.-2017 \\ http://doi.org/10.29194/NJES21010028
}

\begin{abstract}
The present work was designed on producing nanohydroxyapatite layers using electrophoretic deposition (EPD) on 316L stainless steel substrate. The EPD coatings were prepared by the deposition of hydroxyapatite (HA)-chitosan nanocomposites on different substrate roughness (polish surface, 220 grit SiC grind, and sand blast surfaces). Depositions were performed using the suspensions of HA nano particles $(3 \mathrm{~g} / \mathrm{L})$ in the mixture of alcohol and distilled water (ethanol, 5 vol. \%water and containing $0.5 \mathrm{~g} / \mathrm{L}$ of chitosan dissolved in 1 vol.\% acetic acid. Coatings were achieved on the cathode at constant voltage, time and temperature $\left(90 \mathrm{~V}, 5 \mathrm{~min}\right.$ and $40{ }^{\circ} \mathrm{C}$ respectively); the $\mathrm{pH}$ value was performed and fitted at 4 . After deposition, the coated samples were dried at room temperature for $24 \mathrm{~h}$. The surface topography of coatings was analyzed using atomic force microscopy (AFM). SEM was used to postulate both the surface and the cross section morphology of the coatings. The adhesion bonding between the deposited coatings and substrate were measured using tape tester to evaluate the adhesion bonding between the coating and substrate. The results showed the deposited coatings on sand blasted substrate has less porosity compared with the polish surface and 220 emery paper $\mathrm{SiC}$ grinding substrate respectively. The coating on the sand blasted substrate showed higher nanoroughness $(122 \mathrm{~nm})$, better adhesion bonding (removal area 15\%) and higher thickness layer $(12 \mu \mathrm{m})$ than that of the polish substrate and 220 emery paper SiC grinding substrate.
\end{abstract}

Keywords: Electrophoretic deposition; Hydroxyapatite; Nanocomposite; Chitosan; Adhesion

\section{Introduction}

Coatings of hydroxyapatite (HAP), $\mathrm{Ca}_{10}\left(\mathrm{PO}_{4}\right)_{6}$ $(\mathrm{OH})_{2}$ have been utilized many years ago. They were developed in order to increase the bioactivity of the implant surface. It possesses similar chemical, structural and biological properties with that of the human bone tissue [1]. It leads to be osseointegration. It has many advantageous, but the main one associated with nano HAP coatings is that the nanoparticles are similar to that of inorganic molecules of the human bone [2]. It was used as a bioceramic material in implant coatings studies because of its behavior of bioactivity. It deposits onto the metal implant and has good compatibility with the human composition of bones [3]. Generally, HA has relatively poor and weak mechanical properties [3,4]. It has been used as coating on the surface of metallic materials in order to combine the strength and toughness of the substrate with the bioactivity of HA [5,6]. There are many coating methods have been utilized in order to prepare hydroxyapatite coatings, like chemical solution deposition, plasma spraying, sputtering coating, dip coating, biomimetic coating and electrophoretic deposition [4-7].

Electrophoretic Deposition (EPD) was found to be an active method to prepare ceramic coatings from powder suspension. It was considered as an easy process to achieve nanostructure deposits from colloidal solution. EPD has demonstrated the possibility to realize unique nanostructures as well as novel and complex materials having combinations in a variety of macroscopic shapes, dimensions and arrangements [8]. It has an ability to control the thickness and morphology of the deposited layer via controlling the electrochemical parameters. It also shows higher deposition rates compared with most coating processes and the low cost of equipment purchase [9]. The process was considered as the ceramic particles suspend in a liquid media, migrate in an electric field and deposit on an electrode. The deposit layer (coating) is produced via two steps [10-12]. In the first step an electric field is applied between two electrodes and produces charged particles suspend in a suitable liquid that moving toward the oppositely charged electrode (electrophoresis). In the second step the particles accumulate at the deposition electrode; it creates compact, porous and homogeneous layer (deposition).

Parameters that determine the characteristics of EPD process are those related to the suspension and the process. These are including physical parameters such as the electrical nature of the electrodes and the electrical conditions (voltage/intensity relationship, deposition times, 
etc.) [13]. In order to achieve a high density material, the ceramic deposits obtained by EPD are required sintering process at high temperatures. To avoid the sintering step in many applications which can lead to possible degradation and microstructural damage of the coating, e.g. phase changes and dilatation/contractions, the addition of polymers in combination with the ceramic components were effectively forming organic/inorganic composite coatings [14]. However, there are many studies employed to demonstrate the effect of different parameters affecting the deposition of hydroxyapatite layer, no detail study was performed to postulate the effect of substrate roughness. The most important studies were concentrated on analysis the effect of processing conditions [6,15,16]. The effect of voltage, alternating current (AC) and direct current (DC) fields were also investigated [15-18]. The other relevant work was concentrated on determining the stability of suspension on the quality of layers formed $[1,19,20]$.

The aim of this study is concerned on the effect of surface roughness on the coating roughness, porosity and deposition rate. It also aims to obtain a good bonding between substrate and coatings, since this bonding have an important role in biomedical applications especially in bone replacement applications.

\section{Experimental work}

It is very important to determine the effect of substrate roughness on the reliability of coatings to prepare the stable aqueous suspension and the final outputs. The HA aqueous suspension consisting of $3 \mathrm{~g} / \mathrm{L}$ HA powder (Aldrich) and 0.5 $\mathrm{g} / \mathrm{L}$ of chitosan was dissolved in 1 vol.\% acetic acid and 5 vol.\% distilled water in ethanol alcohol (purity of 99.9\%). The $\mathrm{pH}$ value was selected and fitted at 4 . After stirring for 5 hours, the suspension was further dispersed ultrasonically for $30 \mathrm{~min}$ by using ultrasonic processor. The substrate used is 316L stainless steel having three different reliable surface finishing. These finishing were obtained with alumina polishing, grinding with 220 emery SiC paper and sand blasted. The dimensions of the samples were $20 \times 10 \times 2 \mathrm{~mm}^{3}$. The area exposed for the deposition for all samples was $100 \mathrm{~mm}^{2}$. The samples were cleaned by ethanol alcohol ultrasonically. The distance between the two electrodes was kept constant at $1 \mathrm{~cm}$ in EPD cell. EPD was performed at constant voltage, time and temperature ( $90 \mathrm{~V}, 5 \mathrm{~min}$ and $40{ }^{\circ} \mathrm{C}$ respectively). These variables were selected after detail experimental evaluation. The deposited coatings were then dried in air for 24 hours.

Table1: Values of thickness, porosity and roughness of coating deposited on different surface roughness.

\begin{tabular}{|l|c|c|c|}
\hline Sample & $\begin{array}{c}\text { Thickness, } \\
\mathbf{~ \mathbf { m }}\end{array}$ & $\begin{array}{c}\text { Porosity, } \\
\mathbf{\%}\end{array}$ & Ra, $\mathbf{~ m m}$ \\
\hline $\begin{array}{l}\text { 220 grit grind } \\
\text { sample (grind) }\end{array}$ & 6 & 4.3 & 13.4 \\
\hline $\begin{array}{l}\text { Polished sample } \\
\text { (smooth) }\end{array}$ & 6.7 & 3.63 & 56.7 \\
\hline Sand blast sample & 12 & 2.37 & 122 \\
\hline
\end{tabular}

Optical and scanning electron microscopies were used to study cross section and morphology of coating layers. Atomic force microscopy was used to characterize surface nanoroughness and variant distribution for coatings. In order to clarify the coating bonding with substrate, tape test method was used. Detailed description of experimental procedures can be found other else [21].

\section{Results and discussion}

Microhardness of the substrate is an important key factor in EPD process especially in bone replacement applications. It is covered the requirement for application of implants. It is related directly with bonding between the implant and host bone which accelerates the fixation of this implant when founded in human body. Table 1 shows that the deposited coatings on sand blast substrate have less porosity compared with the polish and 220 grit $\mathrm{SiC}$ grinding substrates. On the other hand, the roughness of the coat deposited on the sand blasted substrate was higher than that of polish and 220 grit SiC grind substrates. This is related strongly to the changing of electrophoretic characteristic during the process. Changing the roughness of the substrate affects the resistivity of the substrate which is contributed highly to the final state of electrophoretic hydroxyapatite deposited layer. Fig. 1 explains the effect of surface roughness on thickness, porosity and roughness values. This figure demonstrates clearly that the best results were obtained after sand blasted. This interesting observation is believed to be due to the changing of resistivity which increasing with increasing the roughness of the substrate (Fig. 2). Increasing the deposition rate is consequently increasing the roughness, but surprisingly reducing the volume fraction of porosity. This is very interesting point needs to be analyzed experimentally and theoretically. 
NJES, Vol.21 No.1, 2018

(a)

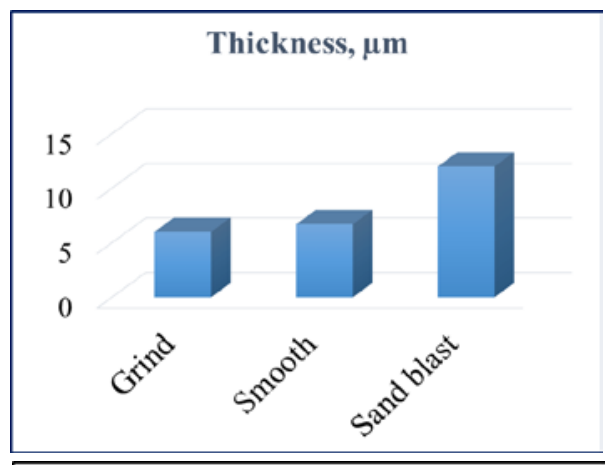

(b)

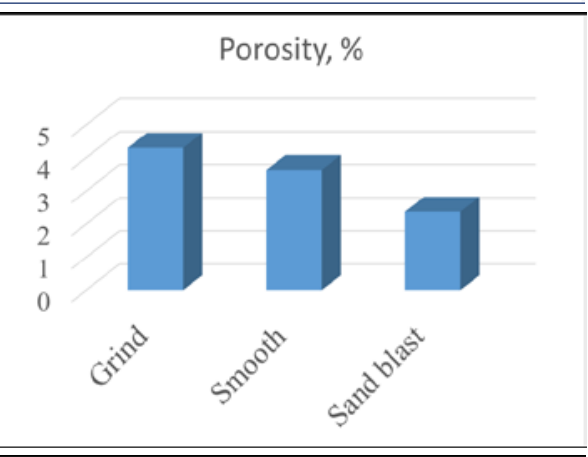

(c)

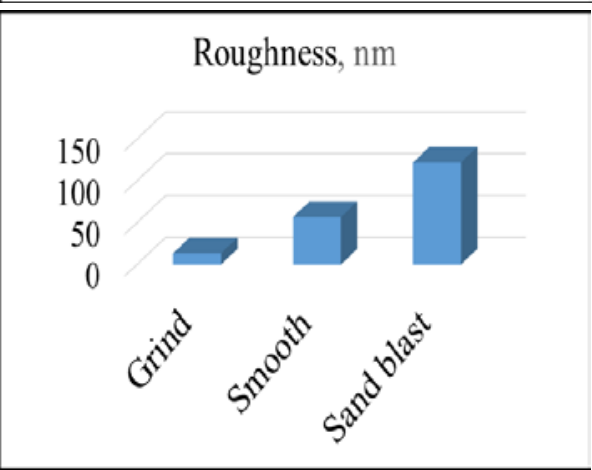

Figure 1: The effect of surface roughness substrate on (a) thickness, (b) porosity (c) roughness of coated layers.

(a)

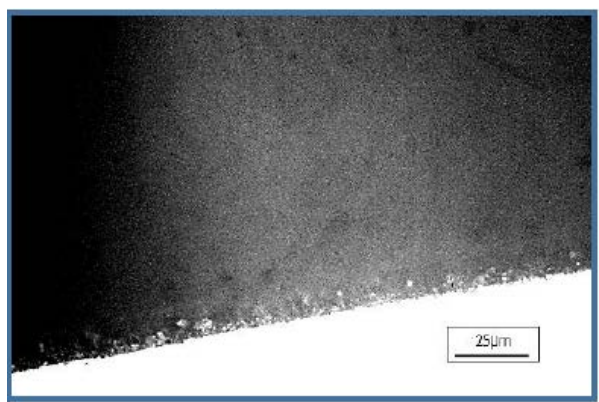

(b)

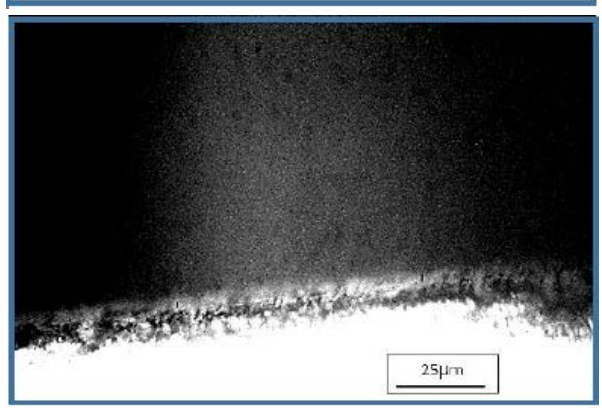

Kadhim et al., pp.28-35

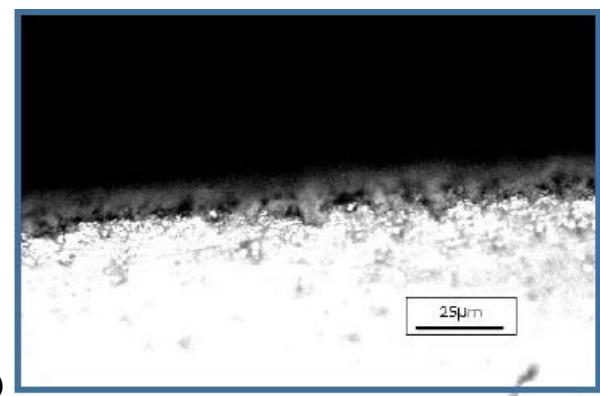

Figure 2: Cross section images of coating layers (a) polished surface, (b) 220 grit grind surface and (c) sand blast surface.

The size of particle deposited on the low roughness substrate is very fine. This is related directly to the low deposition rate (Figs. 3 and 4). The distribution and homogeneity of the particles are relatively uniform at high roughness substrate for grind and sand shoot blast substrates. It was found that the substrate roughness plays an important role in the uniformity of the coatings. The high aglomoration of particles on the polished substrate is due to the low surface tension and secondary physical bonding between particles.
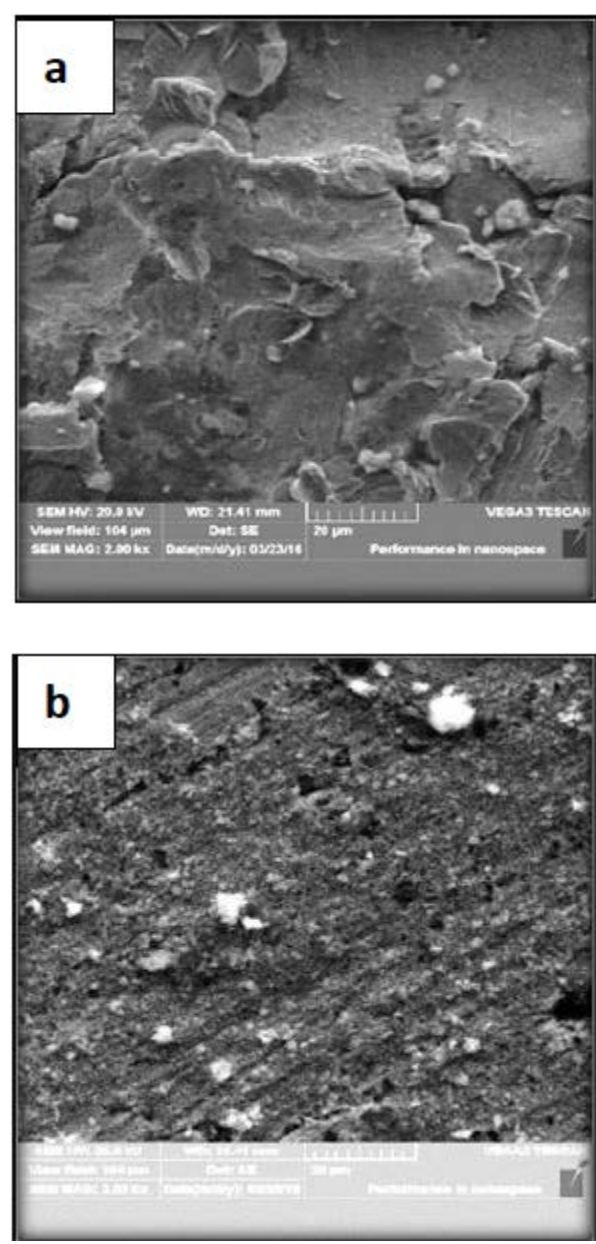

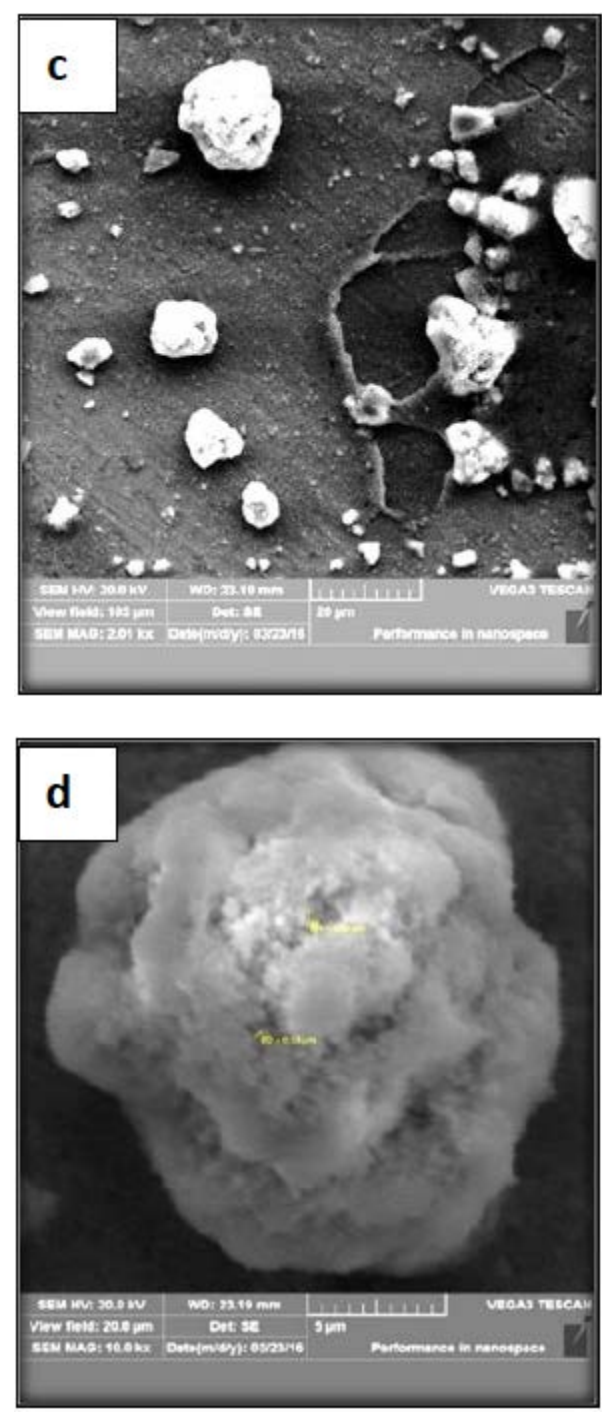

Figure 3: SEM micrographs of HA-chitosan coatings on stainless steel 316L (a) sand blast surface (20 $\mu \mathrm{m})$, (b) 220 grit grind surface (20 $\mu \mathrm{m})$, (c) polish surface $(20 \mu \mathrm{m})$ and (d) agglomeration particles of HA on polish sample (5 $\mu \mathrm{m})$.

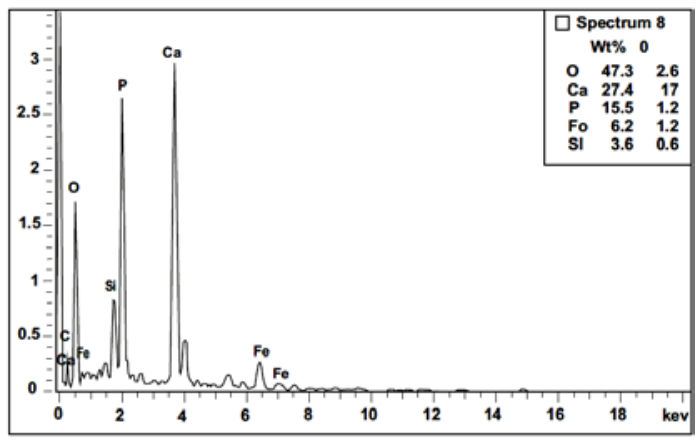

(a)
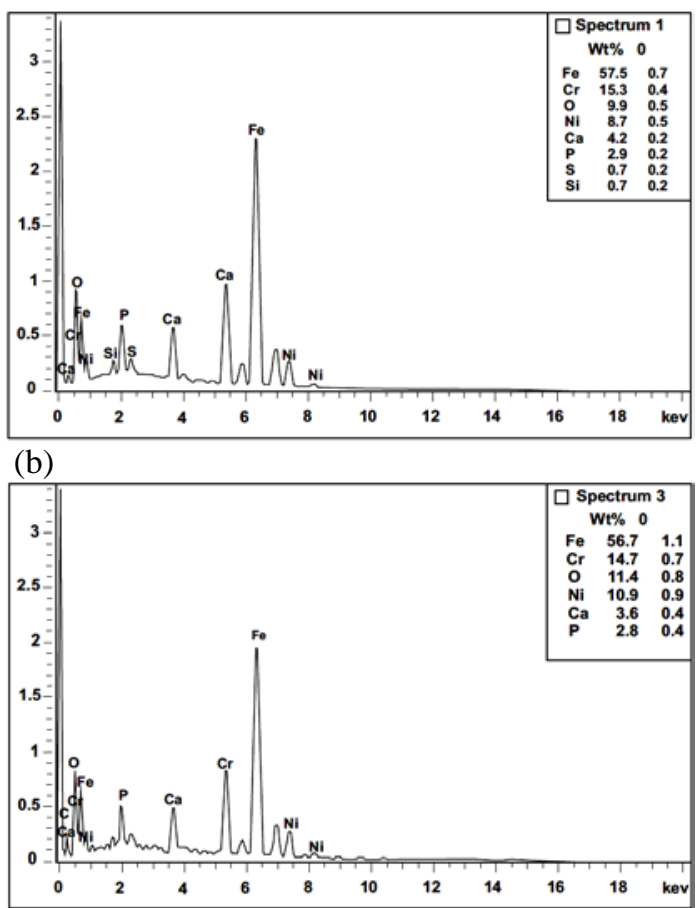

(c)

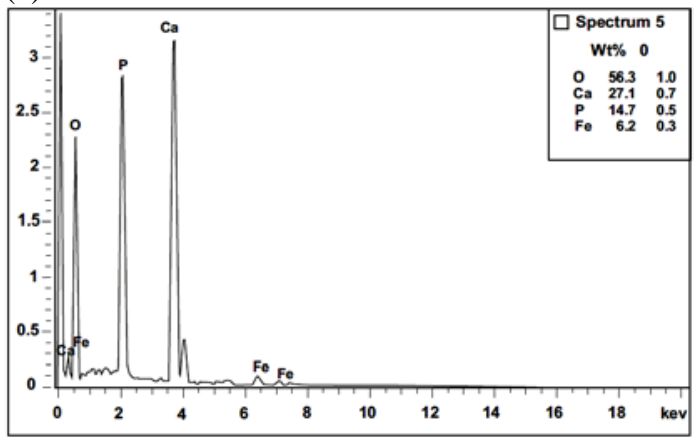

(d)

Figure 4: EDS by SEM of HA-chitosan coatings on SS 316L (a) sand blast surface, (b), 220 grit grind surface, (c) polish surface and (d) agglomeration particles of HA on polish sample.

The roughness analysis was also showed that 220 grit grind substrate has less agglomeration. In both cases (polished and grit ground substrates), many deep porous or holes were found. This is due to the positive charges of the surface which is similar to the particles charge; it leads to a bigger particles size. This is resulted in producing agglomeration of particles which cause evicts the particles during stirring process. There are also many vacancies on the surface resulting in increasing the agglomeration with polished surface as shown in Fig. 3. Energy dispersive analysis (EDS) was used to identify the percentage value of each element composition. The upper surface of the coatings shows that the ratio of $\mathrm{Ca} / \mathrm{P}$ for sand blast sample is approximately 1.76 which is near to the stoichiometric ratio of $\mathrm{Ca} / \mathrm{P}$ (1.67) (Fig. 4). Therefore, the sand blast finishing of surface should be selected for HA deposition coatings. 
AFM test was also confirmed that the highest nanoroughness was presented in the sand blast substrte $(122 \mathrm{~nm})$ as shown in Figs. 5 and 6.

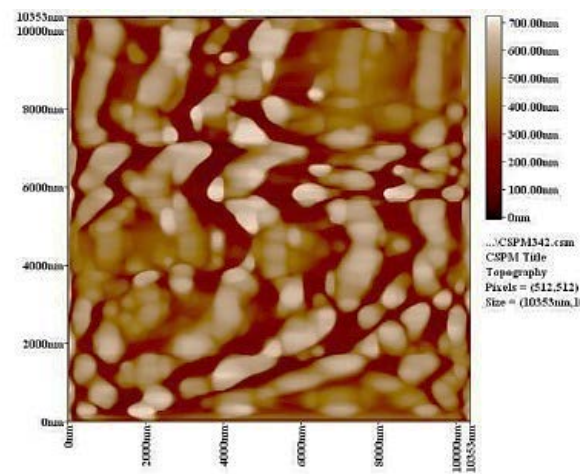

(a)

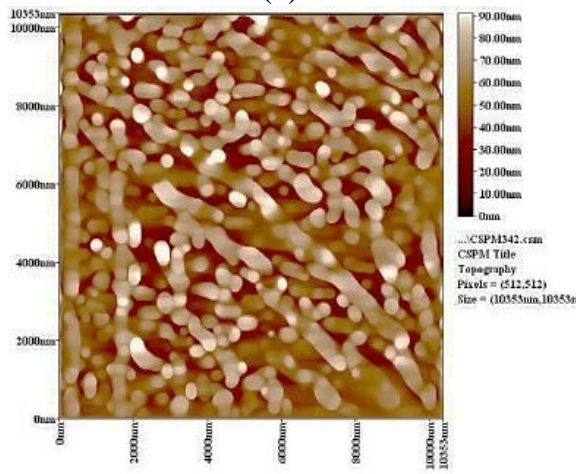

(b)

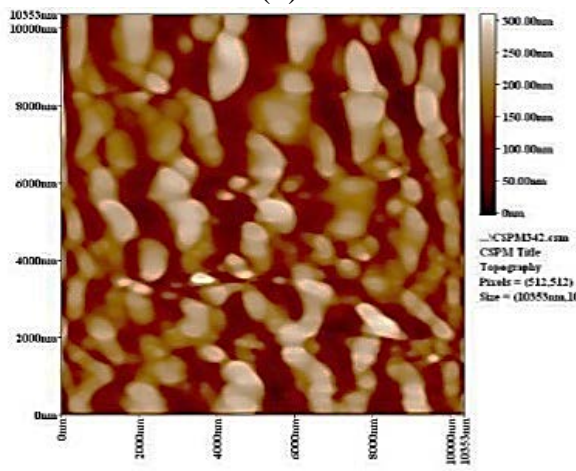

(c)

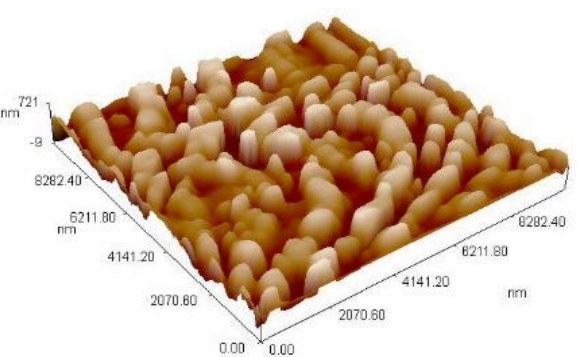

(a)

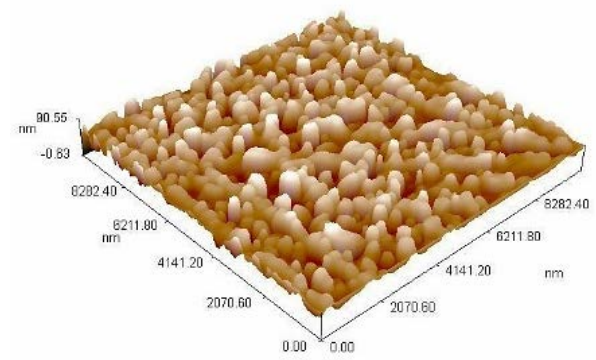

(b)

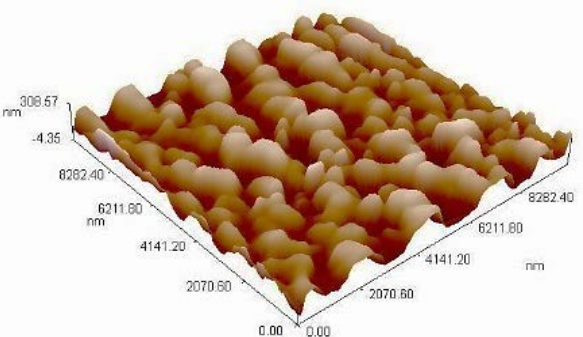

(c)

Figure 6: Three-dimensional image from AFM showing particle density of EPD HA coatings (a) sand blast surface, (b) 220 grit grind surface (c) polished surface.

Particle size analysis of the coatings shows the advantage of sand blasted finishing to obtain lower average size distribution (Tables 2 to 4 ). Charts of granularity accumulation distributions are shown in Fig. 7. This is believed mainly due to the absence of agglomeration which enhances the fine distribution.

Figure 5: Surface roughness showing Ra, (a) sand blast surface, (b) 220 grit grind surface and (c) polish surface.

Table 2: particle size distribution for coating deposited on sand blast surface.

Avg. Diameter: $100.28 \mathrm{~nm}$ $<=50 \%$ Diameter: $90.00 \mathrm{~nm}$

\begin{tabular}{|c|c|c|c|c|c|c|c|c|}
\hline $\begin{array}{l}\text { Diameter } \\
(\mathrm{nm})<\end{array}$ & $\begin{array}{c}\text { Volume } \\
\text { (\%) }\end{array}$ & $\begin{array}{c}\text { Cumulation } \\
\text { (\%) }\end{array}$ & $\begin{array}{l}\text { Diameter } \\
(\mathrm{nm})<\end{array}$ & $\begin{array}{l}\text { Volume } \\
\text { (\%) }\end{array}$ & $\begin{array}{c}\text { Cumulation } \\
\text { (\%) }\end{array}$ & $\begin{array}{c}\text { Diameter } \\
(\mathrm{nm})<\end{array}$ & $\begin{array}{c}\text { Volume } \\
\text { (\%) }\end{array}$ & $\begin{array}{c}\text { Cumulation } \\
\text { (\%) }\end{array}$ \\
\hline 40.00 & 7.88 & 7.88 & 100.00 & 8.50 & 55.04 & & & \\
\hline 50.00 & 3.29 & 11.17 & 110.00 & 7.47 & 62.51 & 10 & $\begin{array}{l}4.25 \\
2.77\end{array}$ & 80. \\
\hline 60.00 & 5.48 & 16.66 & 120.00 & 6.51 & 69.02 & $1 / 0.00$ & $\begin{array}{l}3.11 \\
2.36\end{array}$ & $\begin{array}{l}92.32 \\
05\end{array}$ \\
\hline 70.00 & 10.08 & 26.73 & 130.00 & 6.37 & 75.39 & 180.00 & 3.36 & 95.68 \\
\hline 80.00 & 11.03 & 37.77 & 140.00 & 4.73 & 80.12 & 190.00 & 2.88 & 98.56 \\
\hline 90.00 & 8.77 & 46.54 & 150.00 & 4.18 & 84.30 & 200.00 & 1.44 & 100.00 \\
\hline
\end{tabular}


Table 3: Particle size distribution for coating deposited on 220 grit grind surface.

Avg. Diameter: $107.94 \mathrm{~nm}$ $<=10 \%$ Diameter: $50.00 \mathrm{~nm}$ $<=50 \%$ Diameter: $100.00 \mathrm{~nm}$ $<=90 \%$ Diameter: $170.00 \mathrm{~nm}$

\begin{tabular}{|c|c|c|c|c|c|c|c|c|}
\hline $\begin{array}{c}\text { Diameter } \\
(\mathrm{nm})<\end{array}$ & $\begin{array}{c}\text { Volume } \\
(\%)\end{array}$ & $\begin{array}{c}\text { Cumulation } \\
(\%)\end{array}$ & $\begin{array}{c}\text { Diameter } \\
(\mathrm{nm})<\end{array}$ & $\begin{array}{c}\text { Volume } \\
(\%)\end{array}$ & $\begin{array}{c}\text { Cumulation } \\
(\%)\end{array}$ & $\begin{array}{c}\text { Diameter } \\
(\mathrm{nm})<\end{array}$ & $\begin{array}{c}\text { Volume } \\
(\%)\end{array}$ & $\begin{array}{c}\text { Cumulation } \\
(\%)\end{array}$ \\
\hline 40.00 & 5.22 & 5.22 & 110.00 & 7.74 & 57.18 & 180.00 & 3.36 & 91.71 \\
50.00 & 2.42 & 7.64 & 120.00 & 7.69 & 64.86 & 190.00 & 2.89 & 94.59 \\
60.00 & 5.31 & 12.95 & 130.00 & 6.10 & 70.97 & 200.00 & 1.82 & 96.41 \\
70.00 & 8.11 & 21.06 & 140.00 & 4.57 & 75.54 & 210.00 & 1.91 & 98.32 \\
80.00 & 9.41 & 30.48 & 150.00 & 4.94 & 80.48 & 220.00 & 1.54 & 99.86 \\
90.00 & 9.41 & 39.89 & 160.00 & 4.38 & 84.86 & 230.00 & 0.14 & 100.00 \\
100.00 & 9.55 & 49.44 & 170.00 & 3.49 & 88.35 & & & \\
\hline
\end{tabular}

Table 4: Particle size distribution for coating deposited on polished surface.

Avg. Diameter: $144.20 \mathrm{~nm}$ $<=10 \%$ Diameter: $50.00 \mathrm{~nm}$ $<=50 \%$ Diameter: $110.00 \mathrm{~nm}$ $<=90 \%$ Diameter: $280.00 \mathrm{~nm}$

\begin{tabular}{|c|c|c|c|c|c|c|c|c|}
\hline $\begin{array}{c}\text { Diameter } \\
(\mathrm{nm})<\end{array}$ & $\begin{array}{c}\text { Volume } \\
(\%)\end{array}$ & $\begin{array}{c}\text { Cumulation } \\
(\%)\end{array}$ & $\begin{array}{c}\text { Diameter } \\
(\mathrm{nm})<\end{array}$ & $\begin{array}{c}\text { Volume } \\
(\%)\end{array}$ & $\begin{array}{c}\text { Cumulation } \\
(\%)\end{array}$ & $\begin{array}{c}\text { Diameter } \\
(\mathrm{nm})<\end{array}$ & $\begin{array}{c}\text { Volume } \\
(\%)\end{array}$ & $\begin{array}{c}\text { Cumulation } \\
(\%)\end{array}$ \\
\hline 40.00 & 5.95 & 5.95 & 240.00 & 1.19 & 85.37 & 440.00 & 0.10 & 97.77 \\
50.00 & 2.03 & 7.99 & 250.00 & 1.24 & 86.61 & 450.00 & 0.40 & 98.16 \\
60.00 & 5.65 & 13.64 & 260.00 & 0.84 & 87.45 & 460.00 & 0.25 & 98.41 \\
70.00 & 8.83 & 22.47 & 270.00 & 1.49 & 88.94 & 470.00 & 0.15 & 98.56 \\
80.00 & 8.04 & 30.51 & 280.00 & 0.89 & 89.83 & 480.00 & 0.20 & 98.76 \\
90.00 & 6.20 & 36.71 & 290.00 & 1.04 & 90.87 & 490.00 & 0.25 & 99.01 \\
100.00 & 6.05 & 42.76 & 300.00 & 0.84 & 91.72 & 510.00 & 0.10 & 99.11 \\
110.00 & 5.06 & 47.82 & 310.00 & 1.24 & 92.96 & 520.00 & 0.15 & 99.26 \\
120.00 & 5.11 & 52.93 & 320.00 & 0.60 & 93.55 & 540.00 & 0.05 & 99.31 \\
130.00 & 5.21 & 58.13 & 330.00 & 0.64 & 94.20 & 550.00 & 0.05 & 99.36 \\
140.00 & 3.42 & 61.56 & 340.00 & 0.55 & 94.74 & 560.00 & 0.10 & 99.45 \\
150.00 & 3.67 & 65.23 & 350.00 & 0.30 & 95.04 & 570.00 & 0.10 & 99.55 \\
160.00 & 2.68 & 67.91 & 360.00 & 0.20 & 95.24 & 580.00 & 0.10 & 99.65 \\
170.00 & 3.22 & 71.13 & 370.00 & 0.55 & 95.78 & 590.00 & 0.05 & 99.70 \\
180.00 & 2.78 & 73.91 & 380.00 & 0.69 & 96.48 & 600.00 & 0.05 & 99.75 \\
190.00 & 2.53 & 76.44 & 390.00 & 0.40 & 96.88 & 650.00 & 0.05 & 99.80 \\
200.00 & 1.93 & 78.37 & 400.00 & 0.15 & 97.02 & 690.00 & 0.10 & 99.90 \\
210.00 & 2.38 & 80.75 & 410.00 & 0.30 & 97.32 & 700.00 & 0.05 & 99.95 \\
220.00 & 1.69 & 82.44 & 420.00 & 0.15 & 97.47 & 860.00 & 0.05 & 100.00 \\
230.00 & 1.74 & 84.18 & 430.00 & 0.20 & 97.67 & & \\
\hline
\end{tabular}

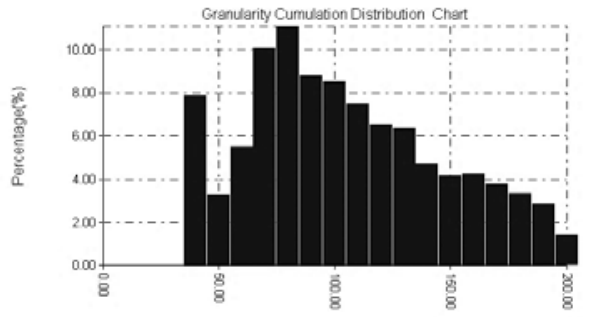

(a)

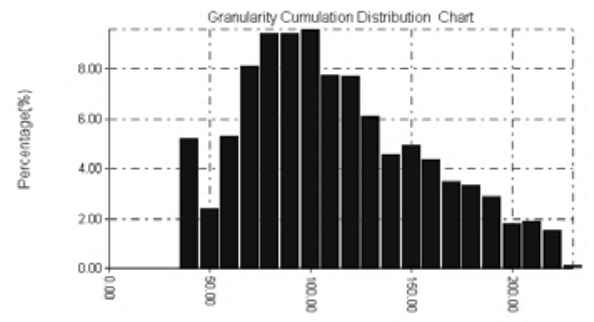

(b)

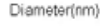

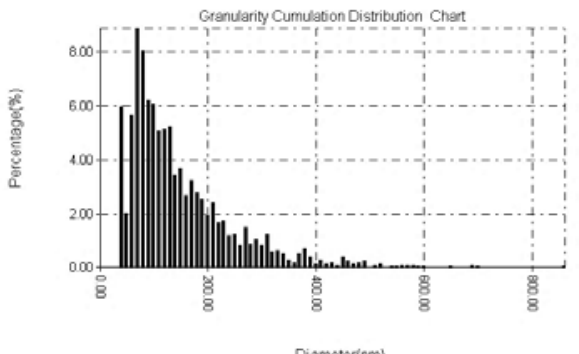

(c)

Fig. 7. Charts of granularity accumulation for coating particles of (a) sand blast surface, (b) 220 grit grind and (c) polished sample.

The contribution of the most three features of the deposit layers (thickness, \% porosity and roughness) are correlated collectively by adhesive tape bonding test. However, this test was used widely to evaluate EPD deposition qualitatively rather than quantitatively, but still reliable to 
evaluate the adhesive bonding. In order to evaluate the qualitatively of bonding between the coating layer and the $316 \mathrm{~L}$ stainless steel substrate, the adhesive tape test method was used. Fig. 8 demonstrates clearly the advantage of sand blasted finishing on the bonding between substrate and EPD layer. There was an improvement of bonding within more than 100\% compares with polish and grind finishing because the percentage of removal area reduced from $37.7 \%$ and 41.09 to $15 \%$. This is simply meant that the coating on the sand blast surface was the best and strongest adhesion. This is a clear indicator that there is a good bonding between coating layer and the sand blast substrate.

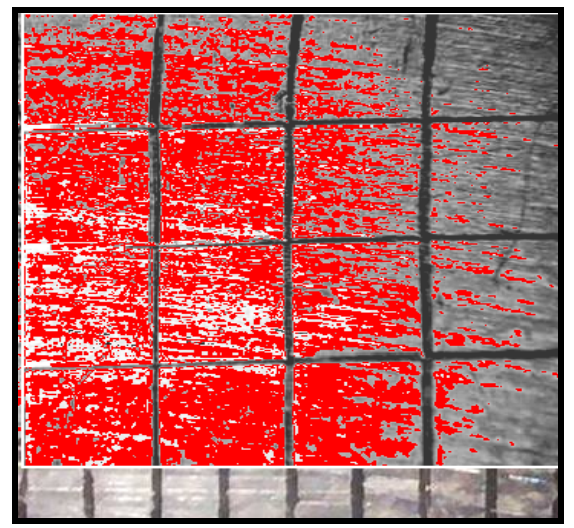

(a) $37.78 \%$

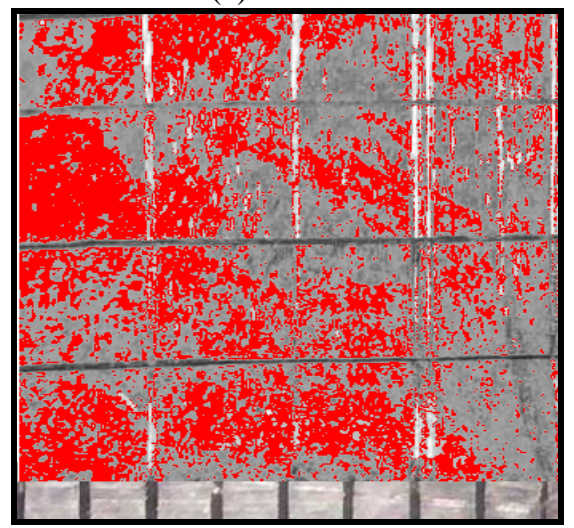

(b) $\% 41.09 \%$

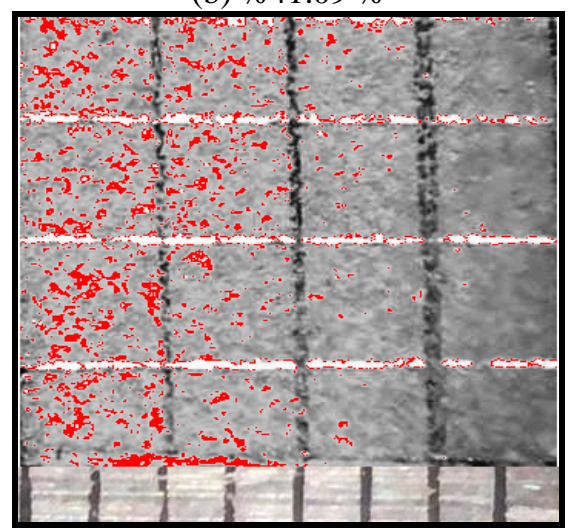

(c) $15 \%$

Fig. 8. Optical images for removal area coatings of single layer on (a) 220 grit grind surface, (b) polished surface and (c) sand blast surface.

\section{Conclusions}

1- It is vital to introduce shot blased finshing to 316L stainless steel substrate to achieve reliable high rate deposition, high roughness and lower porosity for EPD of HA.

2- It is impossible to achieve a reliable EPD of HA on low roughness of 316L stainless steel substrate using polishing or ground finishing.

3- High improvement of adhesive bonding between substrate and hydroxyapatite coating was achieved for the sand blasted surface finishing.

\section{Reference}

1- M.F. Rad, Electrophoretic deposition of hydroxyapatite nanoparticles in different alcohols: Effect of Tris \{tris(hydroxymethyl) aminomethane $\}$ as a dispersant, Ceramic International, 42(2016)3361-3371.

2- L. Mohan, D. Durgalakshmi, M. Geetha, T.S.N. S. Narayanan, R. Asokamani, Electrophoretic deposition of nanocomposite $\left(\mathrm{Hap}+\mathrm{TiO}_{2}\right)$ on titanium alloy for biomedical applications, Ceramics International, 38(2012)3435-3443.

3- M. Mihailovic, A. Pataric, Z. Gulisija, D. Veljovic, D. Janackovic, Electrophoretically deposited nanosized hydroxyapatite coatings on 316L stainless steel for orthopaedic implants, Chemical Industry and Chemical Engineering Quarterly, 17(2011)45-52.

4- A.T. Rada, M. Hashjinc, N.A. Abuosman, S. Faghihi, Improved bio-physical performance of hydroxyapatite coatings obtained by electrophoretic deposition at dynamic voltage, Ceramics International, 40(2014)12681-12691.

5- A.A. Abdeltawab, M.A. Shoeib, S.G. Mohamed, Electrophoretic deposition of hydroxyapatite coatings on titanium from dimethylformamide suspensions, Surface and Coatings Technology, 206(2011)43-50.

6- T.M. Sridhar, U.K. Mudali, M. Subbaiyan, Preparation and characterization of electrophoretically deposited hydroxyapatite coatings on type 316L stainless steel, Corrosion Science, 45(2003)237-252.

7- A. Behnamghadera, N. Bagheria, B. Raissia, T. Foratib, D. Ntentopoulouc, E. Marzbanrada, Electrophoretic deposition of hydroxyapatite, Iranian Journal of Pharmaceutical Sciences, 4(2008)63-68.

8- I. Corni, M.P. Ryan, A.R. Boccaccini, Electrophoretic deposition: From traditional ceramics to nanotechnology, Journal of the European Ceramic Society, 28(2008)1353-1367.

.9- L. Besra, M. Liu, A review on fundamentals and applications of electrophoretic deposition (EPD), Progress in Materials Science, 52(2007)161.

10- R. Boccaccini, S. Keim, R. Ma, Y. Li, I. Zhitomirsky, Electrophoretic deposition of 
biomaterials, Journal Royal Society 7(2010)581613.

11- O. Omer, V.D. Biest, L. J. Vandeperre, Electrophoretic Deposition of Materials, Annual Review of Material Science 29(1999)327-352.

12- I. Zhitomersky, Ceramic films using cathodic electrodeposition, Journal on Mineral, Metal and Materials Society (JOM), e52 (2000).

13- X. Xiu, R.F. Liu, Effect of suspension stability on electrophoretic deposition of hydroxyapatite coatings, Materials Letters 60(2006)2627-2632.

14- L.C. Arias, S.C. Polo, H. Gao, G. Sanchez, J.A. Roether, D.W. Schubert, S. Virtanene, A. R. Boccaccinia, Electrophoretic deposition of nanostructured- $\mathrm{TiO}_{2}$ / chitosan composite coatings on stainless steel, The Royal Society of Chemistry (RSC publishing online) 2013 published on http://pubs.rsc.org DOI: 10.1039/c3ra40535d.

15- P.M. Cortez and G.V. Gutierrez, Electrophoretic deposition of hydroxyapatite submicron particles at high voltages, Materials Letters, 58(2004)336-1339.

16- M. Javidi, S. Javadpour, M.E. Bahrololoom, J. $\mathrm{Ma}$, Electrophoretic deposition of natural hydroxyapatite on medical grade 316L stainless steel, Materials Science and Engineering C, 28(2008)1509-1515.

17- V.O. Kollath, Q. Chen, R. Closset, J.

Luyten, K. Traina, S. Mullens, A. R. Boccaccini, R. Cloots, AC vs. DC electrophoretic deposition of hydroxyapatite on titanium, Journal of the European Ceramic Society, 33(2013)2715-2721. 18- M. Ammam, Electrophoretic deposition under modulated electric fields, a review, RSC

Advances, (2012).7633-7646.

19- S. Mahmoodi, L. Sorkhi, M. Farrokhi-Rad, T. Shahrabi, Electrophoretic deposition of hydroxyapatite-chitosan nanocomposite coatings in different alcohols, Surface and Coatings Technology, 216(2013)106-114.

20- B. Plesingerov, G. Sueik, M. Maryska, D. Horkavcov, Hydroxyapatite coatings deposited from alcohol suspensions by electrophoretic deposition On Titanium Substrate, CeramicsSilikaty, 5(2007)15-23.

21- Makarim Hazim Abdulkareem, optimizing of electrophoretic deposition parameters and characterization of nanobiocomposites functionally graded hydroxyapatite-yttria partially stabilized zirconia, PhD Thesis, Department of Production Engineering and Metallurgy, University of Technology, 2017.

\section{تقيم خشونة السطح للقولاذ المقاوم للصدأ المطلي بطبقة من النانوهيدروكسي اباتايث بطريقة الترسيب الكهربي لمبهي

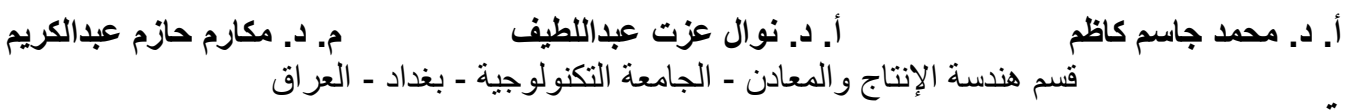

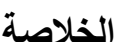

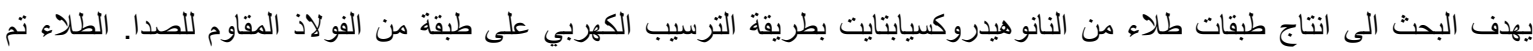

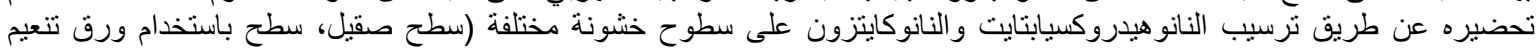

220 وسطح نم تخشينه باستخدام دقائق الرملن).

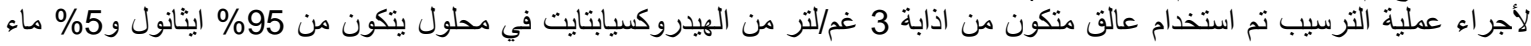

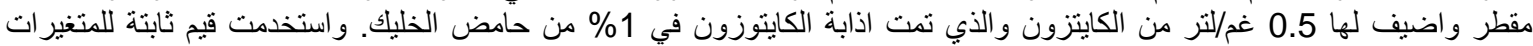

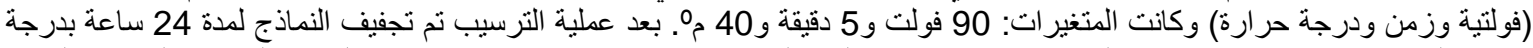

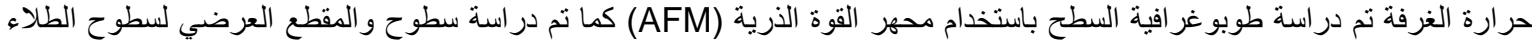

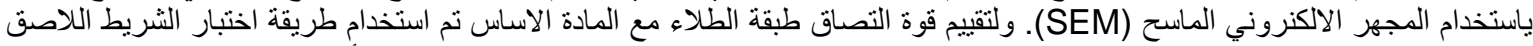
(Tape test)

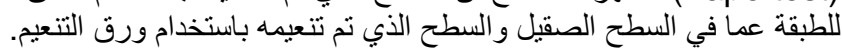

